\title{
ART AS A \\ UNIVERSAL LANGUAGE
}

Solange Ribeiro de Oliveira*

\begin{abstract}
The essay discusses the theoretical question of art as a universal language. The relevance of the theme for studies of intermediality is justified by the relation between the discourses of art history, anthropology and ethnology and artistic objects produced worldwide in different ages. As theoretical support, the essay relies on concepts developed by G. C. Jung, H. Read and E. H. Gombrich, who, in different ways, argue for the universality of art. As illustrations, the text offers reproductions of artworks accessible to the most diverse cultures: representations of archetypes, religious rituals, behavior aimed at the preservation of the species, as well as the exploration of bright colours and the projection of the human form into ordinary utensils.
\end{abstract}

Keywords: Intermediality. The universal in art. Archetypes.

I $\mathrm{n}$ broaching the theme of the universal in art, we are well aware of its problematic aspects. As its detractors claim, "universal" is not a term used to characterize a certain kind of artistic product, identifiable by more or less precise features. Though pretending to be atemporal and absolute, the concept is clearly grounded on the worldview of a legitimating centre - that of European cultures, which look back to Greco-Latin and Jewish Christian roots (LAJOLO, 2005, p. 317).

On the other end of the argument, which I tend to side with, the art critic Hebert Read (1968, p. 219) assures us that in a very real sense art is a universal language, speaking directly to the senses and thus to all humans. In Read's view, the notion supposes a standard of thematic and aesthetic treatment accessible to any observer, regardless of time and place. In the same line, in his praise of rock and popular art, the great Brazilian multi-artist Adriano Suassuna

* Universidade Federal de Minas Gerais (UFMG) - Belo Horizonte - MG - Brasil. E-mail: solanger1@uol.com.br 
(1991, p. 127) affirms that even if expressing an individual's private universe art may become universal by means of its quality and acceptance, as in the work of great poets, who overcome their individual voice to address the whole of mankind. In short, though practiced in different forms, art exists in almost every culture and can be considered one of the defining characteristics of the human species. As ethnologists maintain, all human cultures share some features, institutions, feelings and functions that, in one way or another, are represented in art. Even in its most "primitive" forms, it ultimately responds to certain universal needs, such as individual and group survival, as well as existential questions, most unequivocally expressed in religious art.

In order to tackle such enticing if polemic matters, I begin by facing preliminary questions, among which what is meant by "art" and by "universal". Having considered these matters, I will next probe the hypothesis that art has in fact universal elements, both from a production and from a reception standpoint. In this connection, I will have recourse to theories of art critics and historians, especially Herbert Read and Ernst Hans Gombrich. A survey of artifacts belonging to different categories, created in the most diverse places, cultures and times - including our own - will hopefully clinch my contention that art can indeed be considered a universal language.

Following this scheme of work, we may go back to Read's claim that all art shares certain universal elements. Like Read, Gombrich affirms that the effect of an artwork results from the manipulation of universally available elements, such as lines, colours or tones chosen by the artist. Gombrich (1996b, p. 204) likewise believes in the existence of certain art-related reactions, which are equally universal, as, for instance, the impressions made by light, bright or shining surfaces, as well as by the disgusting and the erotically arousing.

However assertive these statements may sound, they leave untouched two basic questions: What is meant by "art"? And what is meant by "universal"?

Among a number of possible viewpoints, I shall first tackle Leo Tolstoy"s famous claim. In his classical 1897 text, "What is art?" Tolstoy, already a literary legend of worldwide acclaim, emphatically affirmed that, in order to define art, we must first of all cease to take it as a means to pleasure and consider it as one of the conditions of human life. In the great writer's view, art is one of the means of intercourse among men. In Tolstoy's (2016) words:

Art is not, as the metaphysicians say, the manifestation of some mysterious idea of beauty or God; neither is it, as the aesthetical physiologists affirm, a game in which man lets off his excess of stored-up energy; it is not the expression of man's emotions by external signs; it is not the production of pleasing objects; and, above all, it is not pleasure; but it is a means of union among men, joining them together in the same feelings, and indispensable for the life and progress toward the well-being of individuals and of the whole of mankind.

Another definition, by formalist critic Jan Mukařowsky (1977, p. 83) mentions the need for a material object (the "work-thing") which functions as a symbol, whose meaning (called "the aesthetic object") must be significant for members of a community. This definition includes the cultural element, with an important proviso: the significance of the artwork is subject to changes through time. However, the emphasis on meaning shared by a given community fights shy of the universal, which is the object of this discussion. 
Other definitions similarly endorse the idea of communication, with the addition of different qualifications. The anthropologist Richard Anderson (2004, p. 238), for instance, insists that the artwork must be skillfully codified in an instigating sensorial medium, thus recalling Tolstoy"s mention of "pleasing objects". Anderson, however, adds that the object must be culturally significant, which raises a problem: does the author mean a specific culture? In that case, it would join together only the members of a given community, and would not be universal.

One more definition, by the Brazilian poet and critic Ferreira Gullar, further recalls Tolstoy's mention of a "pleasing object". Gullar (2003, p. 125) stresses the need for "formal elaboration", the "deepening of plastic and pictorial signifiers, of reflection and research". More simply, the prestigious art critic Robert Hughes, who died in 1912, defines art as "something to delight the eyes and the spirit".

We get then stranded with the problem that the only common element in these definitions is the need for a material object, leaving the question of the universal untouched. We may cut this Gordian knot by taking simpler and more inclusive definitions, among which the one offered by the Encyclopedia Britannica. In this definition, art is a "visual object or experience consciously created through an expression of skill or imagination" (ENCYCLOPEDIA BRITANNICA, 2012). The definition has the merit of mentioning features found in the most varied cultures, and thus does not exclude the question of universality. Neither does the institutional theory formulated by George Dickie and discussed by Cynthia Freeland (2001, Kindle edition, location 444): any artifact may be considered art, so long as it has been accepted as such by the artworld. The definition would cover all examples of universal art discussed in this paper.

We may then turn to the problem of universality. One of the definitions put forward by Alpha ${ }^{1}$ online dictionary is that "universal" means simply "of worldwide scope or applicability", and thus ignores cultural aspects. However, the dictionary offers a second definition of "universal", that is, "applicable to or common to all members". Another dictionary, Reference ${ }^{2}$, also available online, gives a similar, but not exactly synonymous, definition: the word "universal" implies "used or understood by all". Meaning is here split in two different sections. On one hand, "universal art" would be the kind of art found everywhere ("used by all"), but, on the other, "universal "refers to objects interpretable by everybody ("understood by all"). I initially consider the expression, "used by all", which, in this context, may be taken to refer to art that is created everywhere, in both Eastern and Western cultures. Departing from this point, we may consider Herbert Read's (1968, p. 91) classification of universal art in three types: primitive, peasant, and savage. In fact, the term "Primitive Art" is rather vague and also ethnocentric, since it points to the cultural artifacts of ethnic groups with (by Western standards) a comparatively low evidence of technological development. However, the term has a relatively wide reach, for it includes not only European but also African Art (sub-Saharan), Oceanic Art (Pacific islands), Aboriginal Art (Australia) as well as Rock Art from prehistory and Tribal Art found in the Americas and South-East Asia. Though spread through such wideapart regions of the globe, primitive art embraces remarkably similar items, which can justify its consideration as "universal". The category covers cultural 
products like petroglyphs (rock engravings), paintings and decorative patterns, including, for instance, the rock paintings of the Khoisan groups of South Africa. These have a lot in common with Upper Palaeolithic European cave art. Regional varieties of artistic style are apparent within Africa as well as around the world, without thereby jeopardizing its intelligibility.

As the work of archeologists shows, recent excavations in South African caves have provided significant insight into special skills of so-called primitive peoples, regarding the use of colour, the engraving of patterns, bone technology and bead-making, dating from up to 164 thousand years ago. Recently, engraved drawings attributed to a 15 000-16 000 B.C. culture have been discovered in the Nile Valley. They comprise naturalistic images of animals - aurochs (primitive cattle), hartebeests, gazelles, hippopotami, birds and fishes, and stylized or partial images of humans. These African examples, which prove no less conceptually sophisticated than their European counterparts, contradict former negative ethnocentric evaluations. I may here mention the image of a man's smiling profile ("Profil humain souriant") found in a cave outside the French town Angles-sur-l'Anglin, which dates back to about 15.000 B.C. Equally impressive is the painting of hands found on the walls of Brazilian caves, as in the photo below.

Figure 1 - Hands on Brazilian cave walls (Parque Nacional das Sete Cidades, Piauí, Brazil) ${ }^{3}$.

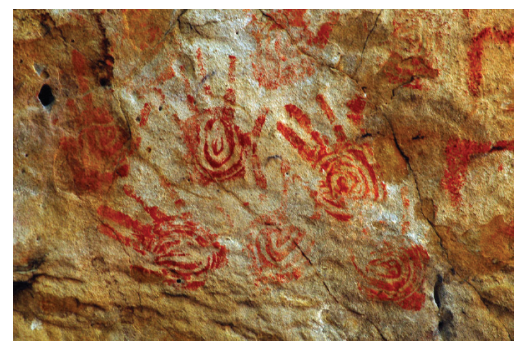

Prints of this kind, produced by blowing pigment around the artists ${ }^{-}$hands and between their fingers, are found throughout worldwide rock art, in European caves and in rocks from Australia, America and South Africa. According to specialists, cave walls were presumably meant to indicate the limits between the realms of the spirits and the ordinary world. The painted hands may thus have had a religious function, invoking supernatural beings, as gestures of adoration or appeals for protection. Also intriguing are the cave paintings found in South Africa, depicting dance scenes, to which experts likewise attribute a ritual, religious function, probably associated with drug-induced altered states of conscience. Attesting to its universality, pre-historic religious art preserves a significant appeal to modern watchers. Among them, the scientist Gillian M Morriss-Kay (2010) reports than on first entering the Lascaux painted cave her predominant reaction was of awe, an overwhelming feeling of reverence, admiration and even fear, associated with religion. If we put aside our modern

3 Available at: <www.flickr.com>. Access on: Feb. 19th, 2016 
DOSSIE

Western secular, scientific world view, the painted hands on prehistoric walls still seem to beckon to us, recalling primeval longings which we may no longer be willing to acknowledge.

Examples of rock art found in other parts of the world could be added ad nauseam, but, for brevity sake, I will limit my examples to the better known images found in European countries - the Chauvet and Lascaux caves, in France, and those of Altamira, in Spain, as well as a famous primitive Venus figure. This tiny selection of works created in different regions thousands of years ago provides food for thought and argues in favour of the universality of art. One example, from the French Chauvet cave, reminds viewers of man's old fascination with horses.

Figure 2 - Chauvet Cave Paintings (France) from 30,000 B.C ${ }^{4}$.

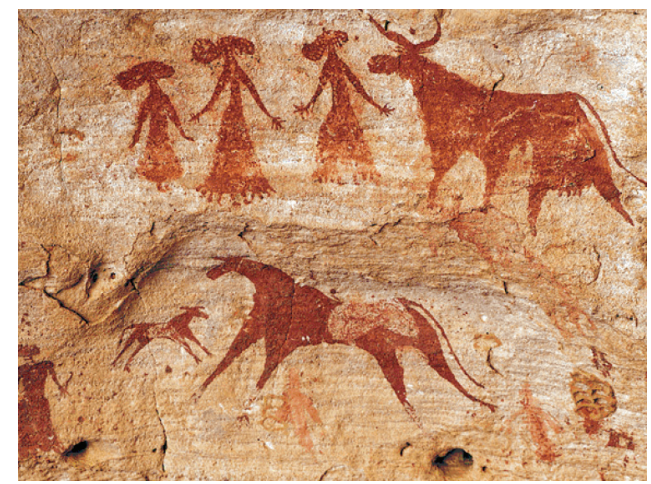

The Altamira paintings - which, presumably, were created as magical strategies to attract prey - include hunters pointing at several animals, as well as mysterious figures with human bodies and animal heads.

Figure 3 - Cave painting, Altamira, Upper Paleolithic cave paintings ${ }^{5}$.

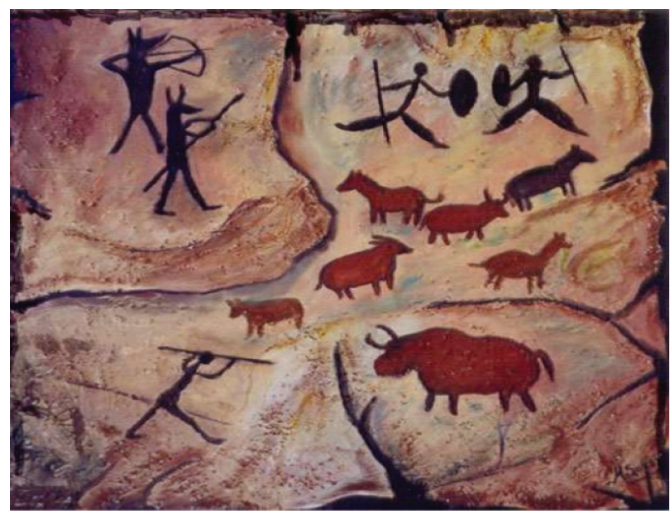


These and a number of other examples demonstrate pre-historic man's ability to create various kinds of proto-art, sometimes of skilled craftsmanship. We may here also remember weapons, personal ornaments, tools made from bone, ivory and stone, with a long cultural history behind them. Such artifacts may have had different functions, difficult to specify: pragmatic, totemic, ritual, marking territory. In the Altamira paintings, one notes the representation of humans with animal heads, as possible indications of shamanic activities. We cannot know whether these figures were created also for the sake of aesthetic pleasure. What stands to reason - and here we reach an argument in favour of the universal - is that they bear witness to two undeniable major drives men share with animals: the preservation of the individual and the preservation of the species. The drive towards preservation is evoked by the representations of the search for food sources, such as hunting. As Gillian M. Morriss-Kay (2010) notes, the instinct for the preservation of the species, concerning sexual behavior, reproduction and parenting, proves likewise inseparable from many images of humans and animals. Venus figurines, frequently found in Upper Paleolithic sites throughout Eurasia, explore these themes. Such figures, dating from up to 27000 years ago, offer exaggerated representations of plump prolific women, presumably nursing their children or about to give birth. In spite of its name, the famous Venus of Vestoniche (circa 27000 BC), the oldest known clay sculpture from the Czech Republic, can in no way be considered beautiful, though its flagrant sexual suggestiveness can hardly be denied.

Figure 4 - Venus of Vestoniche ${ }^{6}$.

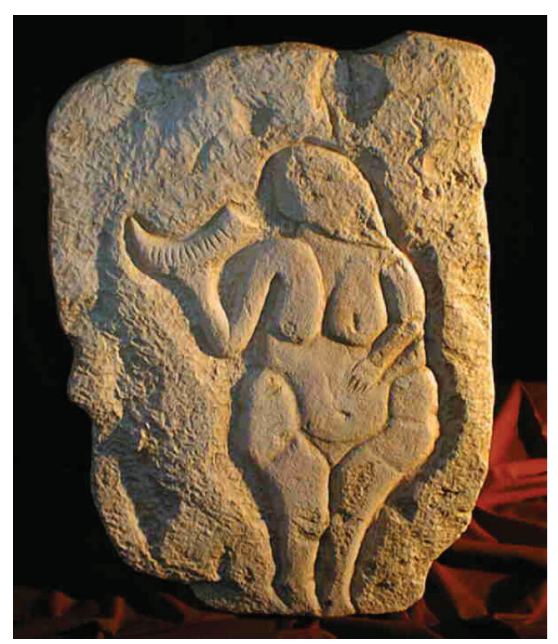

We may well wonder whether the reproductive achievements of the woman thus represented raised her to a cult, even to a goddess, status in her society. The same might be said of the no less famous Venus of Willendorf, a limestone sculpture found in Lower Austria, dated between 30,000 and 22,000 years ago, from the Upper Paleolithic period. Figures like these, archeologists claim, may

6 Available at: <www.auladehistoria.org>. Access on: Feb. 15th, 2016. 
DOSSIE

have played the same role as present-day African fertility dolls, which in many cultures are believed to symbolize fertility goddesses. Also doubtlessly related to the theme of sexuality is the sculpture known as the Ain Sakhri lovers, a stone figurine $10.8 \mathrm{~cm}$ tall and $6.2 \mathrm{~cm}$ wide, dated 9000 B.C., now in the British Museum. Found in 1933 in Cisjordan, it is the oldest known sculpture of humans making love.

Figure 5 - Ain Sakhiri Lovers ${ }^{7}$.

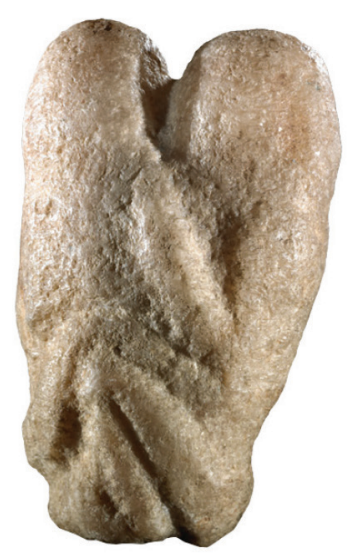

Looking at these interlocked figures, who could deny their kinship with certain modern woks, such as Constantin Brâncusi, 1907, The Kiss? No culture, eastern or western, would fail to recognize here a representation of love as the vehicle for the satisfaction of the individual as well as for the preservation of the species.

Figure 6 - Constantin Brâncusi, The Kiss ${ }^{8}$.

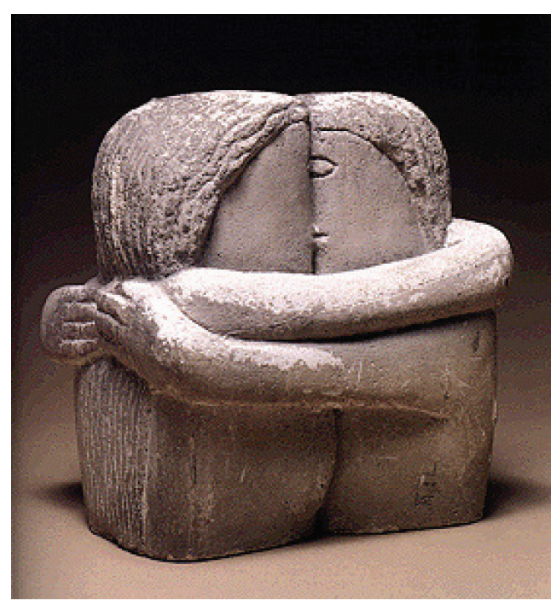


The third universal drive, which man shares with no other animal, is the concern about the origin of humankind and what happens after death. Bearing witness to this anxiety - linked to the existence of religions - prehistoric art offers indications of shamanism, sometimes suggested by the representations of a human body with an animal head. The oldest known example painted on rock is a 32 000-34 000 B.C. red ochre figurine of a man who exhibits what looks like either an animal head or a horned head-dress. A similar figure appears in the Altamira illustration shown above. Even today, animal masks are used in many parts of Africa for ritual purposes. Such purposes may be associated with medicine, divination, the fight against dangerous witches (who are believed to be visible only to the mask-wearer) and with the reincarnation of ancestors. A further example of this kind of art has been found in the Lascaux caves: a charcoal human figure with a bison's head with horn - a drawing with an uncanny resemblance to the Picasso Minotaur 1933 composition Minotaur assaulting girl.

In other respects, too, cave paintings, sculptures and different kinds of prehistoric artifacts show the universal love of art, as instances of sophisticated representational skills and aesthetic sensitivity. Here belongs the decorative use of form and colour mentioned by Gombrich. In all this, Herbert Read points to something that has certainly contributed to the artists' achievements, primitive as well as modern. The philosopher sees them as attempts to escape from the chaos of ordinary experience and from the arbitrariness of life (READ, 1968, p. $42,76)$. By fixing their emotions through art, primitive men may have been trying to preserve something of themselves for all times - a goal traditionally sought by every art form.

Still in the sphere of universality of art, Herbert Read (1968, p. 89) develops some reflections on another kind of creation he considers universal: peasant art. It can be found in objects made by uncultured peoples in accordance with their indigenous traditions, owing little or nothing to outside influences. Such art springs from a desire to impart colour and gaiety to objects of daily use - dress, furniture, pottery carpets. Such artifacts often show a surprising tendency towards abstraction. It may be either geometric abstraction - as in the rugs of Finland, the embroidery of Rumania and the pottery of Peru - or the rhythmical stylization of naturalistic motives, seen in the pottery of central Europe, the carved woodwork of Polynesia and the embroidery of Czechoslovakia. In many cases, as in the Greek Islands and Italy, the two tendencies go hand in hand. One example - a bright-coloured Inca vase - will suffice:

As examples of universal artworks E.G. Gombrich adds some objects whose existence attests to the force of habit. It is this force that leads artists to project in varied objects those forms all of us are most familiar with. In his essay "The force of habit", Gombrich (1996b) asserts that this force explains the human urge for repetition, which has dominated decoration throughout history. In this connection, our perceptual habits, regardless of culture, lead people to project in art some of the sights most deeply ingrained in our minds, especially the form of the human face or body. In the art historian's words,

We are particularly prone to project faces into any configuration remotely permitting this transformation. The tendency may help to account for certain decorative motifs which must have sprung up independently in many parts of the globe. The bulging form of a vessel shaped to hold a liquid has often been 
DOSSIE

endowed with eyes and other facial features to resemble a head, a bird or the semblance of a whole portly figure (GOMBRICH, 1996a, p. 234).

Figure 7 - Inca pottery ${ }^{9}$.

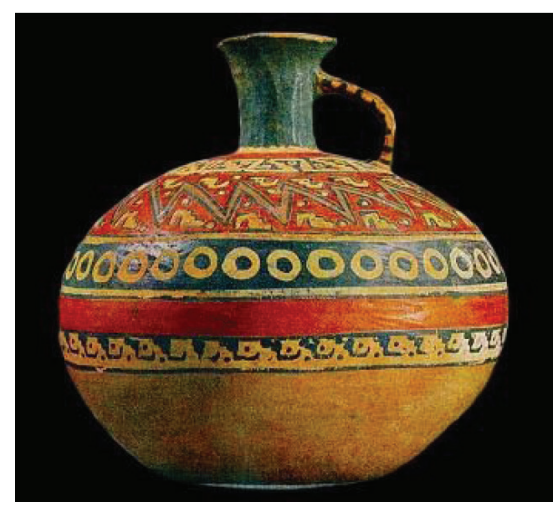

Following this line of argument, Gombrich (1996b, p. 223) describes everyday utensils endowed with human features found in different regions of the globe and in different historical times, as an urn from prehistoric Troy, a Peruvian jug from the $1^{\text {st }}$ millennium A.D., Chinese vessels from the first millennium B.C., Mexican vessels dated 1300-1500, and several others. Among similar examples we may add photos of an Inca vessel.

Figure 8 - Inca ring vessel ${ }^{10}$.

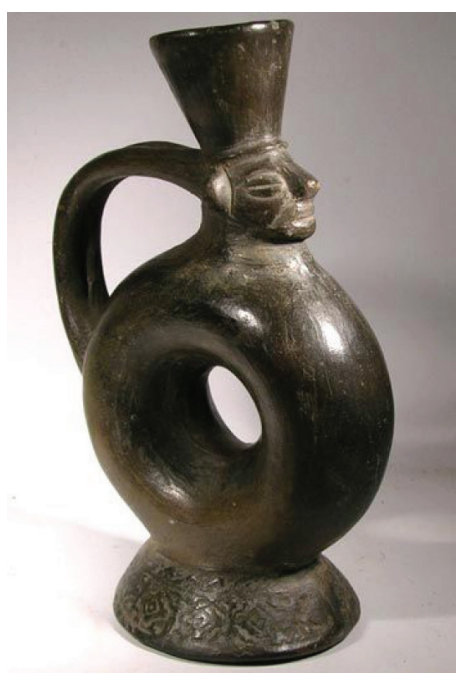


This ageless universal tendency to endow utensils with human features continues to show up in modern art, as in a Picasso's sculpture with strainer and fork:

Figure 9 - Picasso sculpture with strainer and fork ${ }^{11}$.

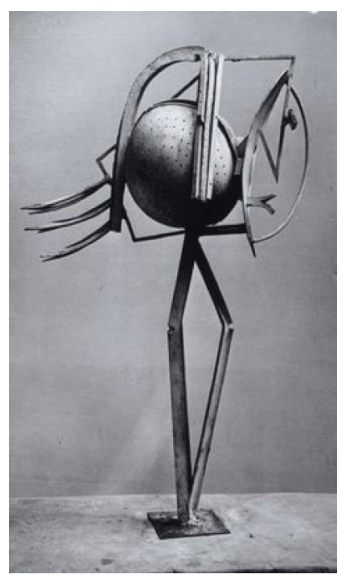

The face and the body are not the only features found in artworks. Gombrich (1996b, p. 225, figure 178) likewise mentions the use of clawed legs for supports. As examples he cites objects set far apart in time, including an Egyptian sledge from the $2^{\text {nd }}$ millennium B.C, a Roman table from the 1 st century A.D., an eighteenth-century dinner table, and even a Victorian piano with bizarrely draped legs, explained by the prudery of the times. Gombrich adds that these and similar habits of "animation" are often reinforced by the belief in the efficacy of eyes, limbs or claws as support or protection against evil. Even when such superstitious beliefs may be considered to have been superseded, the tendency to endow objects with human or animal features persists, as illustrated by the photo of modern furniture pieces.

Figure 10 - Modern furniture with human limbs ${ }^{12}$.

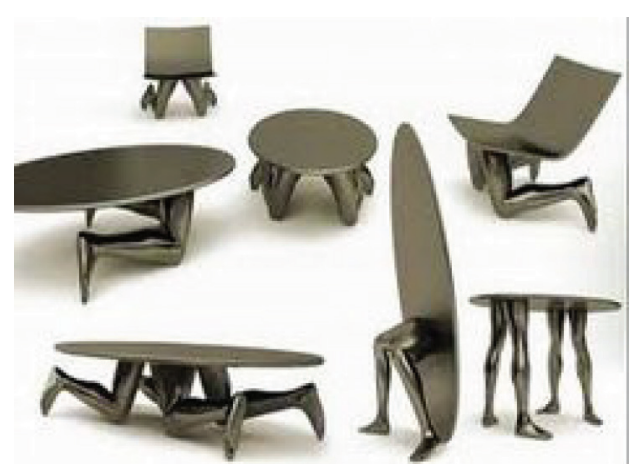

11 Available at: <www.pinterest.com>. Access on: February 12th, 2016.

12 Available at: <www.pinterest.com>. Access on: Feb. 14th, 2016. 
Herbert Read adds other examples, which strongly argue in favour of the universality of art. As an art critic and philosopher, Read explores Jung's theory of archetypes, roughly defined as collectively-inherited unconscious ideas or patterns of thought, regarded as the psychic counterpart of instinct. Being universally inherited potentials, these archaic remnants are actualized when they enter consciousness, under the guise of images or of manifest behavior in interaction with the outside world. Such images furnish an important tool for the appreciation of the kind of art most remarkable from the point of view of perception - the capacity, illustrated by some art works, to be understood by the most diverse cultures. Jung's theory does not refer to psychology alone. It explores the fields of mythology, folklore and religion. It dives into mankind's bottomless past, whose accumulated experience has been the object of studies by ethnography, social psychology and cultural anthropology. Such works, Read (2005, p. 152) adds, take men out of the flux of history to place them in their own group space.

Some of the best known archetypes underlie such images as the mother, the child, the trickster, the flood, the warrior, the virgin, the horse, the phallus as well as other constantly recurring symbols or motifs in mythology and art. Embodying archetypes, certain artworks prove undeniably universal, which explains their atemporal appeal. Here belong examples of cave art illustrated above - images of lovers, pregnant women, warriors, hunters and horses. In contemporary art, similar images can easily be found. Which human viewer would fail to understand the basic meanings ingrained in illustrations belonging to such different art forms as comics, film, sculpture, installations, performances? I begin with Jacob Epstein's 1929 Genesis, a mother figure accessible to all cultures:

Figure 11 - Jacob Epstein: Genesis ${ }^{13}$.

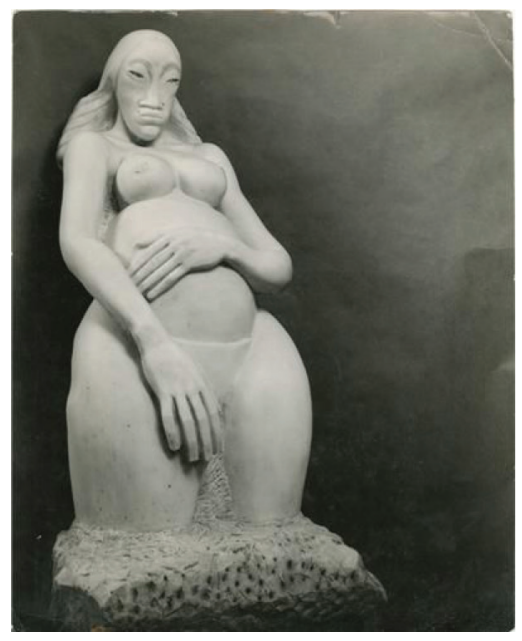

A similar claim could be made for the representation of a hunter in Frank Miller's film Sin City, based on a graphic novel, or of a warrior in 300, the 1998 
comic series by Frank Miller and Lynn Varley. It would be hard to find anything most universally appealing than the image of the hunter or of the hero facing formidable odds.

Figure 12 - The hunter in Frank Miller's Sin city ${ }^{14}$.

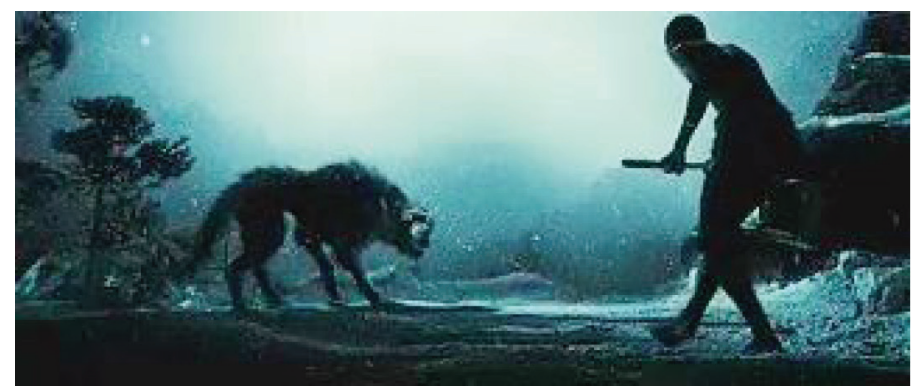

Figure 13 - Frank Miller's Warrior from 300, the 1998 - comic series ${ }^{15}$.

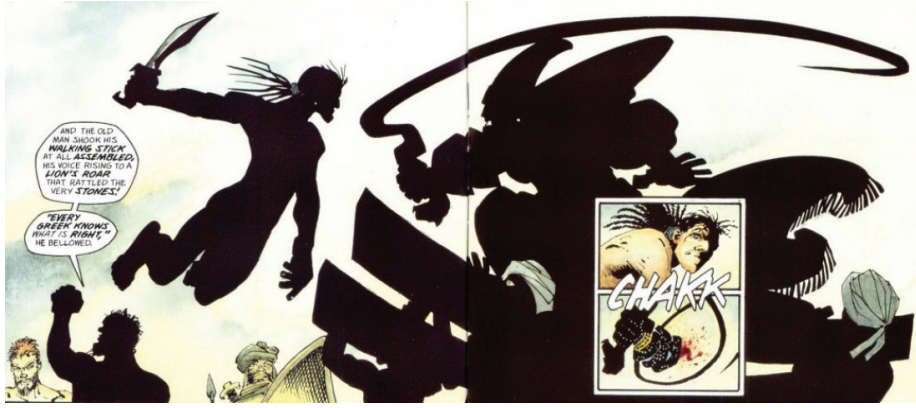

As to the representation of animals, so frequent in the art of all times, we can cite Damien Hirst's 2009 installation Black Sheep with Golden Horns. The animal itself, preserved in formaldehyde, is enclosed in a glass painted stainless steel case, with details in silicone, acrylic gold and cable ties. The technological aids made possible in modern times have little to do with the recognition of the atemporal image. Universal meaning is also encoded in the coupling of a woman's body and a skeleton in the photo Nude with Skeleton, a register of Marina Abramovic's groundbreaking performance work, from March 14 to May 31, 2010. The artist uses her own body as subject, object, and medium, exploring the physical and mental limits of her being - a kind of vanitas, a reminder of the inevitability of death, which haunts all humans.

The same universal topos - the transience of human life - emerges in Damien Hurst's 2007 sculpture For the Love of God. The 32 platinum plates in the skull are set with diamonds, weighing a massive $1,106.18$ carats. The teeth inserted into the jaw are real and belong to the original skull. Purchased from a London taxidermist, it was subjected to intensive bio-archaeological analysis and

14 Available at: <www.pinterest.com>. Access on: Apr. 22nd, 2016.

15 Available at: <www.ebay.co.uk>. Access on: Apr. 22nd, 2016. 
radiocarbon dating. This research revealed the skull dated from around 17201810, and was likely to be that of a 35-year-old man of European/Mediterranean ancestry. The artwork combines the imagery suggestive of the classic memento mori theme with inspiration drawn from Aztec skulls and the Mexican love of decoration towards death.

Figure 14 - Marina Abramovic's 2010 performance Nude with Skeleton

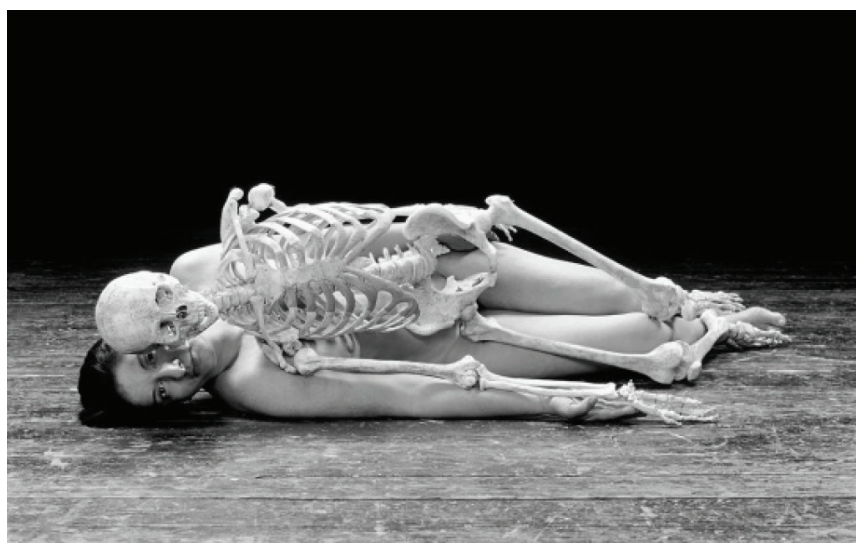

Source: Courtesy of the Marina Abramovic's archives.

Countless other examples could be added whose universal appeal and accessibility would be hard to deny. The ones I have mentioned will, however, suffice. A pair of lovers, a pregnant woman, a brave hunter, fierce warriors, death - the juxtaposition of a young woman's image with that of a skeleton they all appeal to unconscious patterns of thoughts shared by the whole of mankind, no matter whether they are the creation of unknown artists lost in the darkness of the past or works by contemporary artists, who, using the resources of modern technology, seek to project the most basic patterns embodied in archetypal images. In different ways, they speak to all us humans in the universal language of art.

\section{A ARTE COMO LINGUAGEM UNIVERSAL}

Resumo: O ensaio discute a questão da arte como linguagem universal. A relevância do tema para os Estudos da Intermidialidade justifica-se pela relação entre os discursos da história da arte, da antropologia e da etnologia e objetos artísticos produzidos mundo afora através do tempo. A propósito, discutem-se conceitos de G. C. Jung, H. Read e E. H. Gombrich, sustentando a universalidade da arte. Como ilustração, oferecem-se reproduções de objetos artísticos criados em diversas épocas e acessiveis às mais diversas culturas: representações de arquétipos, rituais religiosos, atos visando à sobrevivência da espécie, bem como a exploração de cores vivas e a projeção da forma humana em utensílios comuns.

Palavras-chave: Intermidialidade. Universalidade da arte. Arquétipos. 


\section{REFERÊNCIAS}

ANDERSON, R. Calliope's sisters: a comparative study of philosophies of art. 2 . ed. New Jersey: Pearson Prentice Hall, 2004.

ENCYCLOPEDIA BRITANNICA. Art. 2012. Available at: <http://www.britannica.com/EBchecked/topic/art>. Acess on: May $8^{\text {th }} 2016$.

FREELAND, C. But is it art? An introduction to art theory. New York: Oxford, 2001. Kindle edition.

GOMBRICH, E. H. Verbal wit as a paradigm of art: the aesthetic theories of Sigmund/ Sigmund Freud. In: The Essential Gombrich. London: Phaidon Press, 1996a. p. 189-210.

GOMBRICH, E. H. The force of habit. In: The Essential Gombrich. London: Phaidon Press, 1996b. p. 223-256.

GULLAR, F. Argumentação contra a morte da arte. Rio de Janeiro: Revan, 2003. LAJOLO, M. Regionalismo e história da literatura: quem é o vilão da história? In: FREITAS, M. C. (Org.). Historiografia brasileira em perspectiva. 6. ed. São Paulo: Contexto, 2005. p. 297-328.

MORRISS-KAY, G. M. The evolution of human artistic creativity. Journal of Anatomy, v. 216, n. 2, p. 158-176, Feb. 2010.

MUKAŘOWSKY, J. Art as a semiotic fact. In: BURBANK, J.; STEINER, P. (Ed.). Structure Sign and Function. New Hale; London: Yale University Press, 1977. p. 82-87.

READ, H. The meaning of art. New York; Washington: Preager Publishers, 1968. Revised edition.

READ, H. O sentido da arte. 4. ed. Tradução E. Jacy Monteiro. São Paulo: Ibrasa, 1978. Rept. 2005.

SUASSUNA, A. Uma teoria da arte rupestre. In: SIMPÓSIO DE PRÉ-HISTÓRIA DO NORDESTE BRASILEIRO, 1., 1991, Recife. Anais... Recife: CNPq, UFPE, 1991. p. 127-131.

TOLSTOY, L. What is art? Available at: <https://www.brainpickings.org/2013>. Acess on: May $8^{\text {th }} 2016$.

Recebido em novembro de 2016.

Aprovado em janeiro de 2017. 